\section{ANALISIS KINERJA DAN PERENCANAAN RUANG HENTI KHUSUS (RHK) SEPEDA MOTOR PADA SIMPANG BERSINYAL DI KOTA DENPASAR(STUDI KASUS: SIMPANG NOJA-SARASWATI)}

I Made Kariyana ${ }^{1)}$, Gede Sumarda ${ }^{2)}$ dan I Gusti Ayu Made Ratih Nuratni ${ }^{3, *)}$

${ }^{1}$ Program Studi Teknik Sipil, Fakultas Sains dan Teknologi, Universitas Ngurah Rai, madekariyana@gmail.com

${ }^{2}$ Program Studi Teknik Sipil, Fakultas Sains dan Teknologi, Universitas Ngurah Rai, gdsumarda@gmail.com

${ }^{3}$ Program Studi Teknik Sipil, Fakultas Sains dan Teknologi, Universitas Ngurah Rai, ratihnuratni78@gmail.com

\section{ABSTRAK}

Denpasar adalah ibu Kota dari Provinsi Bali, yang merupakan pusat dari semua kegiatan dengan jumlah kepemilikan kendaraan sebanyak $33 \%$ dari total kendaraan di Provinsi Bali, dimana $82 \%$ kendaraan merupakan sepeda motor tentunya berdampak terhadap kinerja simpang bersinyal sehingga perlu disediakan fasilitas ruang henti khusus (RHK) bagi sepeda motor di persimpangan. Saat pandemi Covid-19 melanda Indonesia khususnya Kota Denpasar tentunya berdampak pada berkurangnya kepadatan lalu lintas sehingga terjadi perubahan kinerja jaringan jalan. Tujuan dari penelitian ini adalah untuk mengetahui kinerja dan disain RHK yang sesuai dengan ketentuan PUPR 2015 pada simpang bersinyal dengan harapan kinerja persimpangan menjadi lebih efektif. Dalam penentuan kinerja simpang bersinyal digunakan ketentuan sesuai Manual Kapasitas Jalan Indonesia (MKJI 1997) sedangkan untuk menentukan disain RHK digunakan Dekstop \& Mobile Web Application (Kementerian PU, 2013). Hasil analisis kinerja bersinyal pada Simpang Noja-Saraswati saat terjadi pandemi Covid-19 mempunyai nilai derajat kejenuhan (DS) yang sama pada pendekat Utara, Timur, Selatan, Barat yaitu 0.740. Untuk nilai panjang antrian masing masing pendekat yaitu pendekat Utara 60m, Timur 89m, Selatan 50m, Barat 55m. Untuk nilai tundaan pendekat Utara 20.8 det/smp, Timur 5.3 det/smp, Selatan 34.5 det/smp, Barat 13.5 det/smp. Desain RHK tipe $P$ untuk pendekat Timur dan Kotak untuk pendekat Barat dengan lebar $2 \times 3.5 \mathrm{~m}$ dan panjang utama $8 m$, pendekat tipe $P$ memiliki dimensi lajur 3.5m. Untuk pendekat Utara dan Selatan tidak dapat didesain RHK karena lebar pendekat tidak memenuhi syarat minimal $3.5 \mathrm{~m}$.

Kata Kunci : simpang bersinyal, kinerja simpang, MKJI 1997, ruang henti khusus.

\section{ABSTRACT}

Denpasar is the capital city of Bali Province, which is the center of all activities with a total vehicle ownership of $33 \%$ of the total vehicles in Bali Province, of which $82 \%$ of vehicles are motorcycles. ) for motorcycles at the intersection. When the Covid-19 pandemic hit Indonesia, especially Denpasar City, it certainly had an impact on reducing traffic density, resulting in changes in road network performance. The purpose of this study is to determine the performance and design of RHK in accordance with the provisions of PUPR 2015 at signalized intersections in the hope that the performance of the intersection will be more effective. In determining the performance of signalized intersections, the provisions according to the Indonesian Road Capacity Manual (MKJI 1997) are used, while the Desktop \& Mobile Web Application is used to determine the RHK design (Ministry of Public Works, 2013). The results of the

Jurnal "MITSU" Media Informasi Teknik Sipil UNIJA Volume 9, No. 2, Oktober 2021 e-ISSN 2685-9173 
performance analysis signaled at the NojaSaraswati intersection during the Covid-19 pandemic had the same degree of saturation (DS) in the North, East, South, West approaches, which was 0.740. For the value of the queue length of each approach, namely the North approach 60m, East 89m, South 50m, West 55m. For the North approach delay value is $20.8 \mathrm{sec} / \mathrm{pcu}$, East $5.3 \mathrm{sec} / \mathrm{pcu}$, South $34.5 \mathrm{sec} / \mathrm{pcu}$, West 13.5 sec/pcu. The RHK type $P$ design for the East approach and the Box for the West approach with a width of $2 \times 3.5 \mathrm{~m}$ and $a$ main length of $8 m$, the $P$ type approach has a lane dimension of $3.5 \mathrm{~m}$. For the North and South approaches, RHK cannot be designed because the width of the approach does not meet the minimum requirement of $3.5 \mathrm{~m}$.

Keywords: signalized intersection, intersection performance, IHCM 1997, advanced stop lines.

\section{PENDAHULUAN}

Denpasar merupakan Ibu Kota Provinsi Bali dimana semua kegiatan terpusat di Kota Denpasar mulai dari pendidikan, ekonomi, dan hiburan. Berdasarkan data Badan Pusat Statistik Provinsi Bali tahun 2020, jumlah kepemilikan kendaraan di Kota Denpasar adalah sebanyak 33\% dari total kendaraan di Provinsi Bali, dimana $82 \%$ kendaraan merupakan sepeda motor. Kondisi tersebut tentunya berdampak terhadap kinerja jaringan jalan khususnya kinerja simpang bersinyal di Kota Denpasar (Kariyana dkk., 2019).

Simpang adalah simpul dalam jaringan jalan dimana dua atau lebih ruas jalan bertemu, disini arus lalu lintas mengalami konflik. Terdapat dua jenis persimpangan jalan dari segi pandangan untuk kontrol kendaraan, yaitu persimpangan dengan sinyal dan persimpangan tanpa sinyal. Untuk mengurangi permasalahan yang terjadi pada persimpangan, khususnya simpang bersinyal, maka Pemerintah Kota Denpasar menerapkan ruang henti khusus (RHK). Ruang henti khusus merupakan satu fasilitas sepeda motor dalam bentuk penyediaan fasilitas ruang henti khusus (RHK) kendaraan sepeda motor dipersimpangan (Kementrian Pekerjaan Umum dan Perumahan Rakyat, 2015). Dengan terkumpulnya sepeda motor didepan kendaraan lain diharapkan sepeda motor dapat bermanuver lebih cepat pada saat lampu hijau menyala, yang tentunya dapat mengurangi waktu kehilangan awal.

Saat ini dunia sedang mengalami pandemi Covid-19 termasuk di Indonesia. Hal ini tentunya berdampak pada pola pergerakan masyarakat, dimana sebelum terjadi pandemik saat pergerakan masyarakat masih normal terjadi kepadatan lalu lintas yang sangat tinggi. Sedangkan saat terjadi pandemik dimana Pemerintah Bali mengadakan Pembatasan Kegiatan Masyarakat (PKM) serta work from home atau bekerja dan belajar dari rumah dengan tujuan untuk mengurangi aktivitas masyarakat di luar rumah, tentunya kepadatan lalu lintas menjadi menurun sehingga kinerja jalan menjadi lebih baik.

Berdasarkan survei pendahuluan yang dilaksanakan pada 6 Februari 2020 sebelum terjadinya pandemi Covid-19, Simpang Noja - Saraswati merupakan simpang yang padat dimana terdapat penumpukan sepeda motor pada jam sibuk lebih dari 30 kendaraan yang mengakibatkan terjadinya antrian dan tundaan pada persimpangan. Dari beberapa penelitian terdahulu terkait RHK seperti, Yulianto dkk (2016), Rangkuiti, (2017), Roesdyningtyas, dkk, (2016), dan lain lain belum ada yang menganalisis tentang kinerja simpang dan disain RHK saat pandemi Covid-19, serta belum ada penelitian terkait RHK yang dilakukan di Simpang Noja - Saraswati, Denpasar-Bali. Maka dari itu peneliti ingin mengetahui kinerja simpang bersinyal di Simpang Noja - Saraswati saat terjadi 
pandemi Covid-19 dan merencanakan ruang henti khusus (RHK) sesuai dengan ketentuan PUPR 2015.

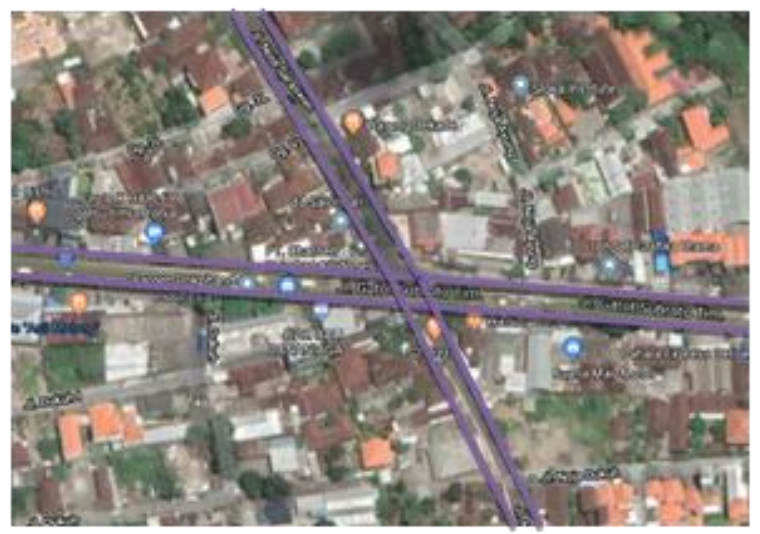

Gambar 1.

Simpang Noja - Saraswati

(Sumber: Google Map, 2020)

\section{METODE PENELITIAN}

Metodologi yang digunakan dalam menyelesaikan studi penelitian ini yaitu studi pendahuluan, pengumpulan data dan tahap analisis data. Pada tahap studi pendahuluan penulis melakukan pencarian dan pengumpulan informasi yang berkaitan mengenai topik penelitian. Hal ini bertujuan untuk memudahkan pekerjaan analisis berikutnya. Pada survei pendahuluan menentukan lokasi dimana terdapat 30 penumpukan kendaraan sepeda motor sepanjang Jalan Gatot Subroto. Maka didapatkan titik lokasi pada Simpang Noja - Saraswati.

\subsection{Prosedur Penelitian}

Sebelum melakukan analisis data terlebih dahulu menetapkan alur penelitian seperti Gambar 2.

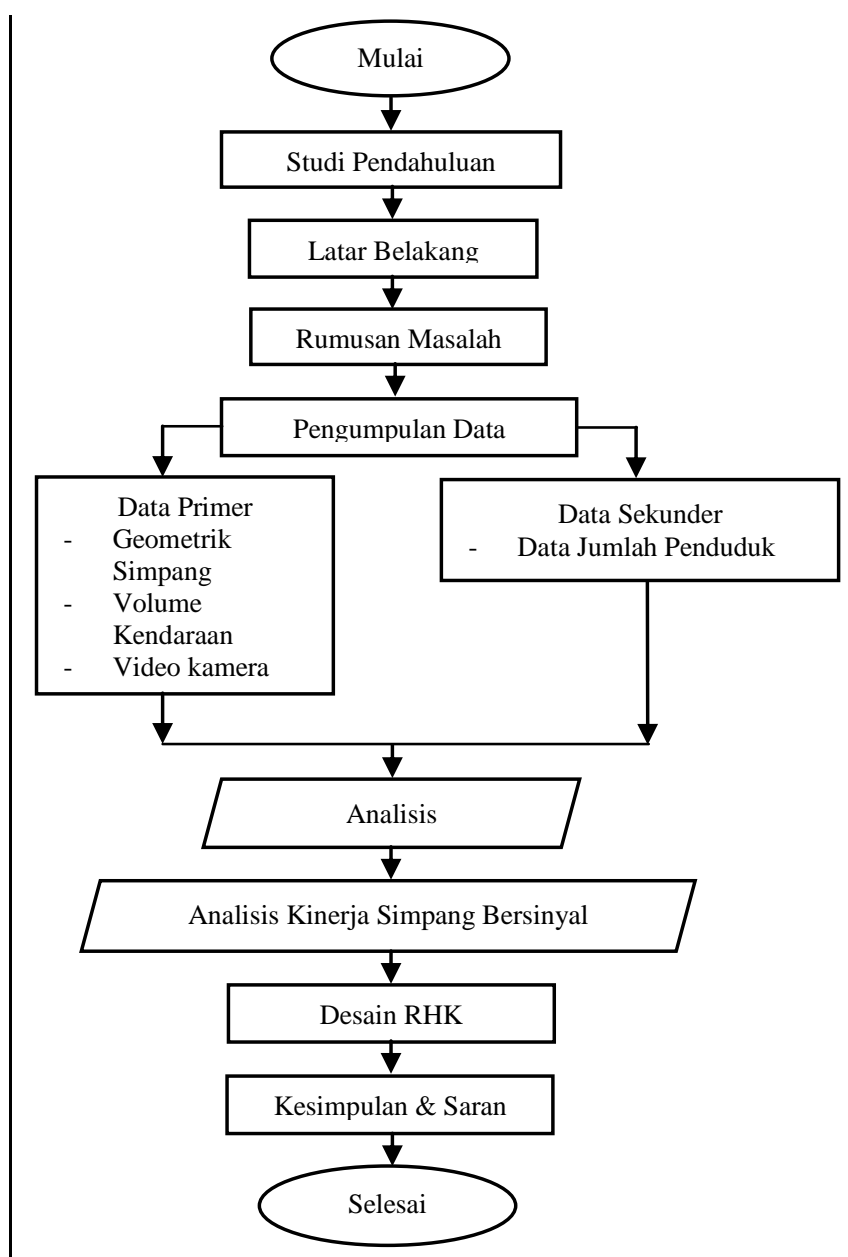

Gambar 2.

Diagram Alir Metode Penelitian

\subsection{Metode Penelitian}

Metodologi yang digunakan dalam menyelesaikan studi penelitian ini yaitu studi pendahuluan, pengumpulan data dan tahap analisis data. Pada tahap studi pendahuluan penulis melakukan pencarian dan pengumpulan informasi yang berkaitan mengenai topik penelitian. Hal ini bertujuan untuk memudahkan pekerjaan analisis berikutnya. Pada survei pendahuluan menentukan lokasi dimana terdapat 30 penumpukan kendaraan sepeda motor sepanjang Jalan Gatot Subroto. Maka didapatkan titik lokasi pada Simpang Noja - Saraswati.

\subsection{Sumber Data}

Pengumpulan data dilakukan dengan mengambil data primer yang dilakukan 
secara langsung di lapangan atau dengan menggunakan video kamera. Sedangkan pengumpulan data sekunder dilakukan menggunakan data dari Badan Pusat Statistik (BPS). Parameter yang dijadikan acuan yaitu untuk kinerja lalu lintas adalah volume lalu lintas yang nantinya menghasilkan derajat kejenuhan (DS, degree of saturation) pada ruas jalan, dan besarnya tundaan (delay) serta panjang atrian (queue) pada suatu simpang.

\subsection{Teknik Pengambilan Data}

Dalam pengambilan data (survei) lapangan dilakukan dengan rekaman video menggunakan kamera pada titik simpang yang sudah ditentukan yaitu di Simpang Noja - Saraswati. Dilakukan 1 hari selama 2 jam pada jam sibuk pagi, siang dan sore kendaraan dengan pertimbangan data yang akan dianalisis berupa data kendaraan per jam (kend/jam) yang dikalikan dengan satuan mobil penumpang (smp) maka data berupa smp/jam. Berdasarkan tujuan dari penelitian ini, teknik pengambilan data tersebut dapat diperjelas sebagai berikut:

1. Waktu pelaksanaan survei dilaksanakan pada 18 Juni 2020. Waktu menghitung rekaman video dilaksanakan pada 29 Juni 2020.

2. Persiapan peralatan pengambilan data di lapangan seperti kamera video (xiaomi dan gopro), tripod, powerbank, kabel data dan alat pengukur geometrik simpang (meteran digital).

3. Survei utama yaitu mulai dari merekam data di lapangan, lalu memindahkan hasil rekaman ke laptop setelah itu memutar kembali hasil rekaman video dan menghitung volume kendaraan.

\section{HASIL DAN PEMBAHASAN}

Berikut merupakan hasil dan pembahasan analisis kinerja simpang bersinyal dengan metode Manual Kapasitas Jalan Indonesia (MKJI) 1997 dan perencanaan ruang henti khusus di Simpang Noja - Saraswati.

\subsection{Analisis Kinerja Simpang Bersinyal}

Tabel di bawah merupakan tabel data geometrik yang didapat dari hasil survei lapangan pada 18 Juni 2020.

Tabel 1.

\begin{tabular}{|c|c|c|c|c|c|c|}
\hline \multirow{2}{*}{$\begin{array}{c}\text { Kaki } \\
\text { Simpang }\end{array}$} & \multirow{2}{*}{$\begin{array}{c}\text { Lebar } \\
\text { Perkerasan } \\
(\mathrm{m})\end{array}$} & \multirow{2}{*}{$\begin{array}{c}\text { Jumlah } \\
\text { Lajur } \\
\text { Pada } \\
\text { Pendekat }\end{array}$} & \multicolumn{2}{|c|}{$\begin{array}{c}\text { Lebar } \\
\text { Pendekat (m) }\end{array}$} & \multirow{2}{*}{$\begin{array}{c}\text { Lebar } \\
\text { Trotoar } \\
(\mathrm{m})\end{array}$} & \multirow{2}{*}{$\begin{array}{c}\text { Lebar } \\
\text { Bahu } \\
\text { Jalan } \\
(\mathrm{m})\end{array}$} \\
\hline & & & $\begin{array}{c}\text { Wmasuk } \\
(\mathrm{m})\end{array}$ & $\begin{array}{c}\text { Wkeluar } \\
\text { (m) }\end{array}$ & & \\
\hline $\begin{array}{c}\text { Jl. } \\
\text { Noja } \\
\text { Saraswati }\end{array}$ & 6 & 2 & 3 & 3 & - & - \\
\hline $\begin{array}{c}\text { Jl. } \\
\text { Gatsu } \\
\text { Timur }\end{array}$ & 11.9 & 4 & 5.6 & 6.3 & 1.4 & 0.7 \\
\hline $\begin{array}{c}\text { Jl. } \\
\text { Noja }\end{array}$ & 5.9 & 2 & 2.8 & 3.1 & 1.2 & 0.4 \\
\hline $\begin{array}{c}\text { Jl. } \\
\text { Gatsu } \\
\text { Barat }\end{array}$ & 11.7 & 4 & 6.6 & 5.1 & 1.4 & 0.4 \\
\hline
\end{tabular}

(Sumber : Analisis, 2020)

Pemilihan tipe pendekat simpang (approach) yaitu terdapat dua tipe pendekat antara lain yang termasuk tipe pendekat pelindung ( protected $=\mathrm{P}$ ) atau tipe pendekat terlawan ( opossed $=\mathrm{O}$ ).

Tipe simpang pada simpang Noja Saraswati termasuk tipe pendekat terlawan (O). Tipe pendekat terlawan dapat dilihat pada gambar berikut: 


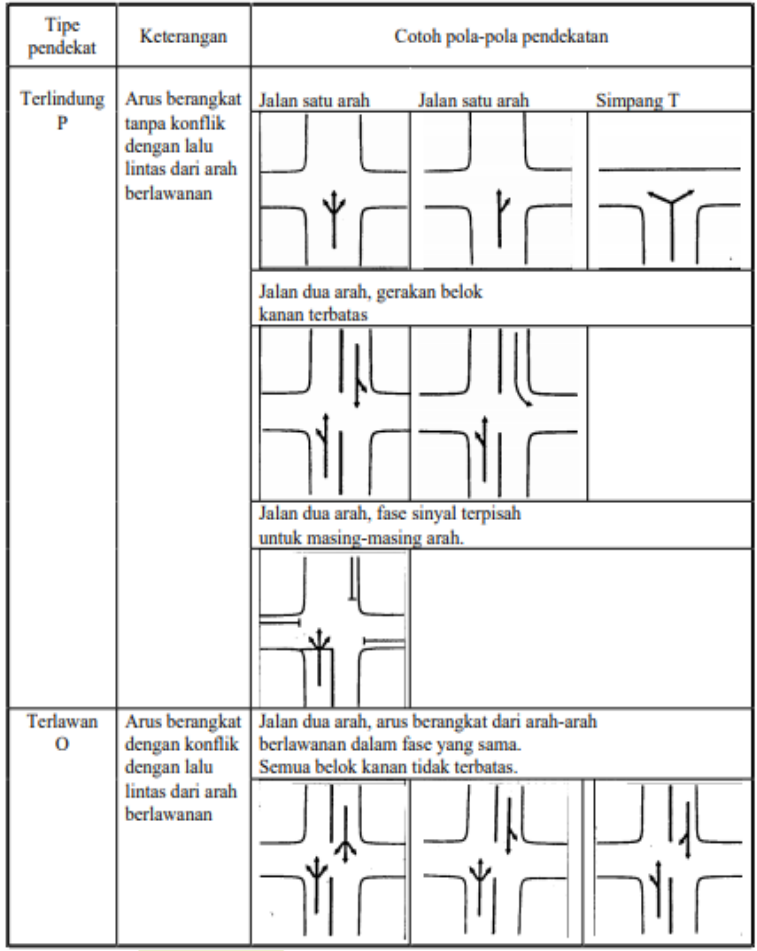

Gambar 3.

Penentuan Tipe Pendekat

Tabel di bawah merupakan potongan tabel arus lalu lintas yang diambil dari tabel formulir SIG I.

Tabel 2.

Aruslalulintas

\begin{tabular}{|c|c|c|}
\hline \multirow{2}{*}{ KodePendekat } & \multicolumn{2}{|c|}{ KendaraanBermotor Total MV } \\
\cline { 2 - 3 } & kend/jam & smp/jam \\
\hline $\mathrm{U}$ & 477 & 304 \\
\hline $\mathrm{T}$ & 2,018 & 1,153 \\
\hline $\mathrm{S}$ & 343 & 140 \\
\hline $\mathrm{B}$ & 1,677 & 938 \\
\hline
\end{tabular}

(Sumber : Analisis, 2020)

Pada Tabel 2 menunjukkan arus lalu lintas terbesar pada pendekat Timur yaitu sebesar 1153 smp/jam. Pada perhitungan pendekat tipe terlawan $(\mathrm{O})$ dengan pendekat tanpa lajur belok kanan terpisah $S_{o}$ ditentukan menggunakan $\mathrm{We}, \mathrm{Q}_{\mathrm{RT}}$ dan $\mathrm{Q}_{\mathrm{RTO}}$ atau dapat menggunakan gambar 4 . pendekat - pendekat tipe o tanpa lajur belok kanan terpisah.

$$
\mathrm{We}=\mathrm{QRT} ; \mathrm{QRTO}
$$

Keterangan:

$\mathrm{Q}_{\mathrm{RT}}$ : Volume kendaraan belok kanan

$\mathrm{Q}_{\mathrm{RTO}}$ : Volume total kendaraan belok kanan
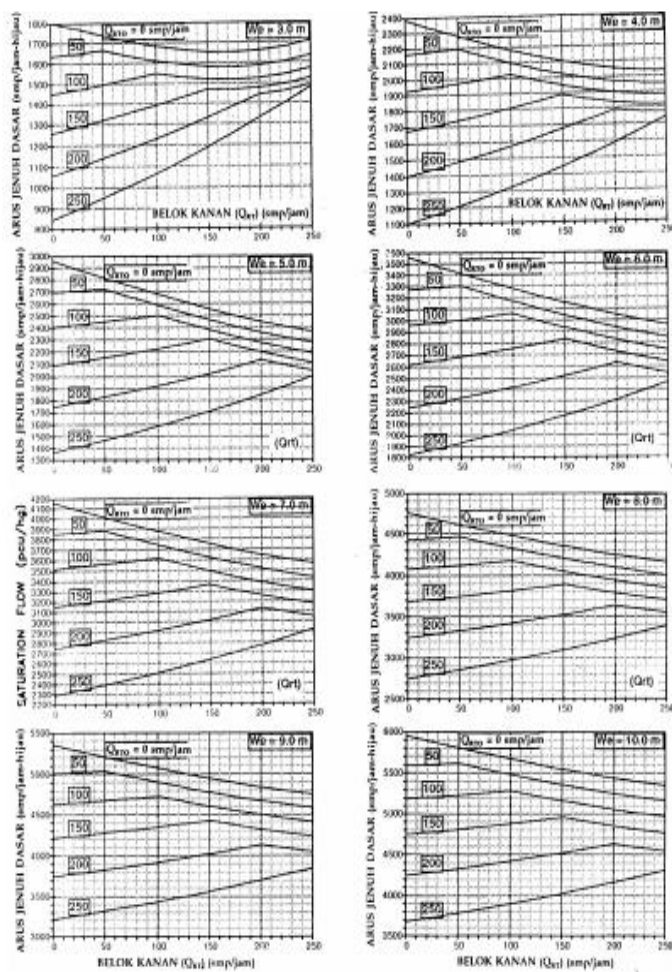

Gambar 4.

Pendekat - Pendekat Tipe O Tanpa Lajur Belok Kanan Terpisah.

(Sumber : Departemen Pekerjaan Umum,1997)

Untuk menghitung arus jenuh dasar dengan menentukan nilai $\mathrm{Q}_{\mathrm{RT}}$ yaitu sebesar 56 smp/jam dan menentukan nilai QRTоуaitu sebesar 27 smp/jam. Dengan menggunakan data geometrik simpang maka didapat $\mathrm{We}=3 \mathrm{~m}$. Menghitung nilai So pada tipe pendekat terlawan maka dapat dihitung dengan langkah sebagai berikut:

Qrt $=56 \mathrm{smp} / \mathrm{jam}$

Qrto $=27 \mathrm{smp} / \mathrm{jam}$

$\mathrm{S}_{3} \quad=1730 \mathrm{smp} / \mathrm{jam}$

$$
\begin{aligned}
\text { So } & =(\mathrm{We}-3.0) \times(\mathrm{S} 3)+(\mathrm{S} 3) \ldots \ldots \ldots \\
& =(3-3.0) \times(1730)+(1730) \\
& =1,730 \mathrm{smp} / \mathrm{jam} .
\end{aligned}
$$

Dalam menghitung arus jenuh dapat dilakukan dengan menghitung faktor 
penyesuaian ukuran kota (Fcs) yang sesuai dengan data jumlah penduduk pada statistik Bali dalam angka 2020 adalah 947,000 jiwa, maka nilai $\mathrm{Fcs}=0.94$, dapat dilihat pada tabel 3. faktor penyesuaian berdasarkan ukuran kota (Fcs). Menentukan faktor penyesuaian hambatan samping (Fsf) dengan menggunakan tabel faktor faktor untuk penyesuaian berdasarkan hambatan samping, maka didapat Fsf $=0.95$. Faktor kelandaian didapat dari melihat pada gambar faktor untuk penyesuaian kelandaian, maka nilai $\mathrm{FG}=1.00$.

Tabel 3.

Faktor penyesuaian berdasarkan ukuran

\begin{tabular}{|c|c|}
\multicolumn{2}{|c}{ kota (Fcs) } \\
\hline Pendudukkota (Juta jiwa) & $\begin{array}{c}\text { FaktorPenyesuaianUkuran Kota } \\
\left(\mathrm{F}_{\mathrm{CS}}\right)\end{array}$ \\
\hline$>3.0$ & 1.05 \\
$1.0-3.0$ & 1.00 \\
$0.5-1.0$ & 0.94 \\
$0.1-0.5$ & 0.83 \\
$<0.1$ & 0.82 \\
\hline
\end{tabular}

(Sumber: Departemen Pekerjaan
Umum,1997)

Menentukan faktor penyesuaian parkir (Fp) dengan menggunakan persamaan :

$\mathrm{FP}=[\mathrm{Lp} / 3-(\mathrm{WA} \times 2) \times(\mathrm{Lp} / 3-\mathrm{g}) / \mathrm{WA}] / \mathrm{g}$

Keterangan:

LP : jarak antara garis henti dan kendaraan yang diparkir pertama (m) atau panjang dari lajur pendek

WA : lebar pendekat (m)

$\mathrm{G}$ : waktu saat hijau dipendekat simpang (nilai normal 26 det)

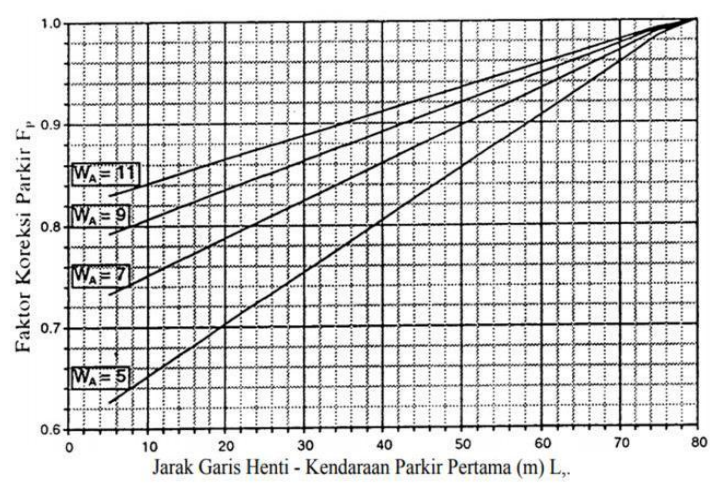

Gambar 5.

Faktor Untuk Penyesuaian Pengaruh Parkir Dan Lajur Belok Kiri Yang Pendek (Fp) ( Sumber: Departemen Pekerjaan Umum, 1997)

$\mathrm{Fp}=0.61$

Untuk menentukan faktor penyesuaian belok kanan (FRT) dengan menggunakan persamaan:

$\mathrm{FRT}=1.0+\mathrm{PRT} \times 0.26$.

Keterangan:

$\mathrm{P}_{\mathrm{RT}} \quad$ : rasio kendaraan berbelok

$\mathrm{FRT}=1.0+\mathrm{PRT} \times 0.26$

$\mathrm{FRT}=1.0+0.18 \times 0.26$

$\mathrm{FRT}=1.05$

Untuk menentukan faktor penyesuaian belok kiri (FLT) dengan menggunakan persamaan:

$\mathrm{FLT}=1,0-$ PLT $\times 0.16$.

Keterangan:

$\mathrm{P}_{\mathrm{LT}} \quad$ : rasio kendaraan berbelok

FLT $=1.0-$ PLT $\times 0.16$

$\mathrm{FLT}=1.0-0.25 \times 0.16$

$\mathrm{FLT}=0.96$

Kemudian untuk menentukan nilai arus jenuh menggunakan persamaan:

$\mathrm{S}=\mathrm{SO} \times \mathrm{FCS} \times$ FSF $\times$ FG $\times$ FP $\times$ FRT $\times$ FLTsmp/jam 
Keterangan:

So : nilai arus jenuh pada kondisi yang ideal

$\mathrm{F}_{\mathrm{CS}}$ : faktor untuk penyesuaian ukuran kota

$\mathrm{F}_{\mathrm{SF}}$ : faktor untuk penyesuaian hambatan samping

$\mathrm{F}_{\mathrm{G}}$ : faktor untuk penyesuaian kelandaian

$\mathrm{F}_{\mathrm{P}}$ : faktor untuk penyesuaian parkir

$\mathrm{F}_{\mathrm{RT}}$ : faktor untuk penyesuaian belok kanan

$\mathrm{F}_{\mathrm{LT}} \quad$ : faktor penyesuaian untuk belok kiri

S=SO $\times$ FCS $\times$ FSF $\times$ FG $\times$ FP $\times$ FRT $x$ FLTsmp/jam

$\mathrm{S}=1,730 \times 0.94 \times 0.95 \times 1.00 \times 0.61 \times 1.05 \times 0.96$

$\mathrm{S}=949 \mathrm{smp} / \mathrm{jam}$

Dalam menganalisis kapasitas simpang $(\mathrm{C})$ menggunakan persamaan:

$\mathrm{C}=\mathrm{S} \times \mathrm{g} / \mathrm{c}$

Keterangan:

C : nilai kapasitas pada pendekat (smp/jam)

$\mathrm{S}$ : nilai arus jenuh pada pendekat $($ smp/jam hijau $=$ smp per-jam hijau $)$

g : waktu saat hijau pendekat (det)

c : siklus waktu pada simpang

$\mathrm{C}=\mathrm{S} \times \mathrm{g} / \mathrm{c}$

$\mathrm{C}=949 \times 24 / 54$

$\mathrm{C}=411 \mathrm{smp} / \mathrm{jam}$

Nilai derajat kejenuhan dapat dihitung menggunakan persamaan:

$\mathrm{DS}=\mathrm{Q} / \mathrm{C}=(\mathrm{Q} \times \mathrm{c}) /(\mathrm{S} \times \mathrm{g})$

Keterangan:

DS : derajat kejenuhan

Q : volume kendaraan (smp/jam)

$\mathrm{C}$ : nilai kapasitas pada pendekat (smp/jam)

g : waktu saat hijau pendekat (det)

c : siklus waktu pada simpang

$\mathrm{DS}=\mathrm{Q} / \mathrm{C}$
$\mathrm{DS}=304 / 411$

$\mathrm{DS}=0.740 \mathrm{smp} / \mathrm{jam}$

Untuk menentukan panjang antrian dapat dilihat pada tabel di bawah.

Tabel 4.

Menentukan panjang antrian

\begin{tabular}{|c|c|c|c|c|c|c|c|c|c|}
\hline \multirow[b]{2}{*}{$\begin{array}{c}\text { Kode } \\
\text { Pendeka } \\
\mathrm{t}\end{array}$} & \multirow{2}{*}{$\begin{array}{c}\text { Arus } \\
\text { lalu } \\
\text { linta } \\
\text { s } \\
\text { smp/ } \\
\text { Jam } \\
\text { Q }\end{array}$} & \multirow{2}{*}{$\begin{array}{l}\text { Kapasita } \\
\text { s smp/ } \\
\text { Jam } \\
\text { C }\end{array}$} & \multirow{2}{*}{$\begin{array}{c}\text { Derajat } \\
\text { Kejenu } \\
\text { han } \\
\text { DS = } \\
\text { Q/C }\end{array}$} & \multirow{2}{*}{$\begin{array}{c}\text { Rasio } \\
\text { hijau } \\
\text { GR }= \\
\mathrm{g} / \mathrm{c}\end{array}$} & \multicolumn{4}{|c|}{$\begin{array}{c}\text { Jumlah kendaraan } \\
\text { Antri } \\
\text { (smp) }\end{array}$} & \multirow{2}{*}{$\begin{array}{l}\text { Panjan } \\
\text { g } \\
\text { antrian } \\
\text { (m) }\end{array}$} \\
\hline & & & & & $N_{1}$ & $N_{2}$ & \begin{tabular}{|c|} 
Total \\
NQ1 \\
+ \\
NQ2 \\
$=$ NQ \\
\end{tabular} & & \\
\hline 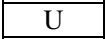 & & & 170 & 0.433 & 0.9 & 3.8 & 4.7 & 9 & 6 \\
\hline $\mathrm{T}$ & 1153 & 1558 & 0.740 & 0.779 & 0.9 & 9.1 & 10.0 & & 8 \\
\hline 3 & 140 & 190 & 0.740 & 0.283 & 0.9 & 1.9 & 2.8 & & 50 \\
\hline B & 938 & 1268 & 0.740 & 0.496 & 0.9 & 11.3 & 12.2 & & 55 \\
\hline
\end{tabular}

(Sumber: Analisis, 2020)

Menentukan tundaan dapat dilihat dalam tabel di berikut ini.

Tabel 5.

Menentukan tundaan

\begin{tabular}{|c|c|c|c|c|c|}
\hline \multirow[b]{2}{*}{$\begin{array}{c}\text { Kode } \\
\text { Pendekat }\end{array}$} & \multirow[b]{2}{*}{$\begin{array}{c}\text { Arus } \\
\text { lalu } \\
\text { lintas } \\
\text { smp/jam } \\
\text { Q }\end{array}$} & \multicolumn{4}{|c|}{ Tundaan } \\
\hline & & \begin{tabular}{|c|} 
Tundaan \\
lalu lintas \\
rata-rata \\
det $/$ smp \\
DT
\end{tabular} & $\begin{array}{c}\text { Tundaan } \\
\text { geometrik } \\
\text { rata-rata } \\
\text { det } / \text { smp DG }\end{array}$ & $\begin{array}{c}\text { Tundaan } \\
\text { rata-rata } \\
\text { det } / \text { smp D } \\
=\mathrm{DT}+ \\
\text { DG }\end{array}$ & $\begin{array}{c}\text { Tundaan } \\
\text { total } \\
\text { smp.det D } \\
\text { x Q }\end{array}$ \\
\hline $\mathrm{U}$ & 304 & 20,8 & 3,9 & 24,7 & 7501 \\
\hline $\mathrm{T}$ & 1153 & 5,3 & 2,5 & 7,7 & 8915 \\
\hline $\mathrm{S}$ & 140 & 34,5 & 3,9 & 38,5 & 5394 \\
\hline $\mathrm{B}$ & 938 & 13,5 & 3,2 & 16,7 & 15679 \\
\hline
\end{tabular}

(Sumber: Analisis, 2020)

3.2 Mendesain Ruang Henti Khusus (RHK) Menggunakan RHK Dekstop \& Mobile Web Application

Mendesain RHK menggunakan aplikasi yang dibuat dari Pusat Penelitian Jalan dan Jembatan. Aplikasi ini bertujuan untuk menentukan sebuah desain perancangan RHK.

Membuka situs web pada google http://rhk.pusjatan.pu.go.id/rhk/rhkapp.php, maka akan terlihat gambar seperti di bawah ini dan klik "Start Program". 

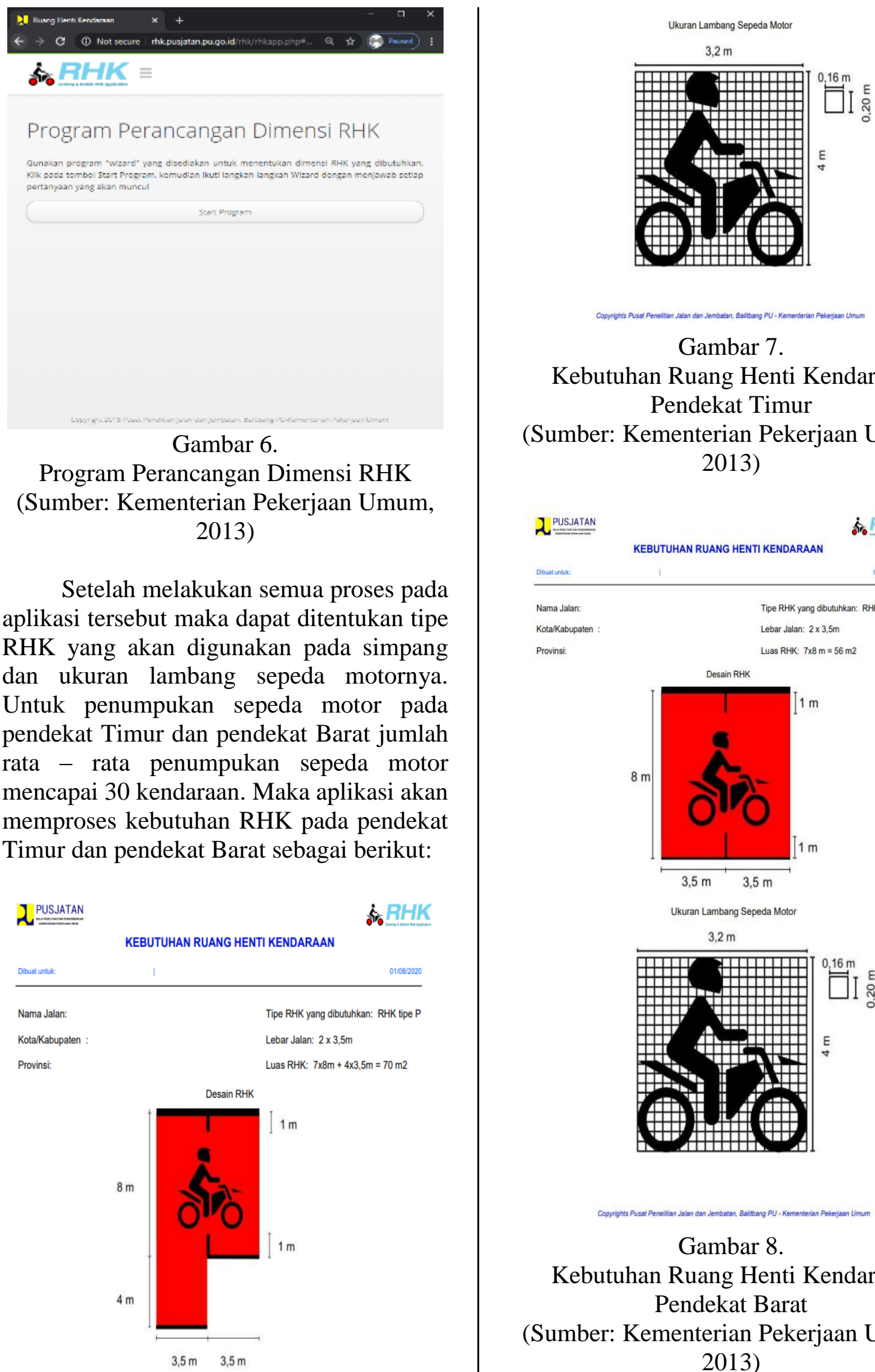

Gambar 7.

Kebutuhan Ruang Henti Kendaraan Pendekat Timur

(Sumber: Kementerian Pekerjaan Umum, 2013)

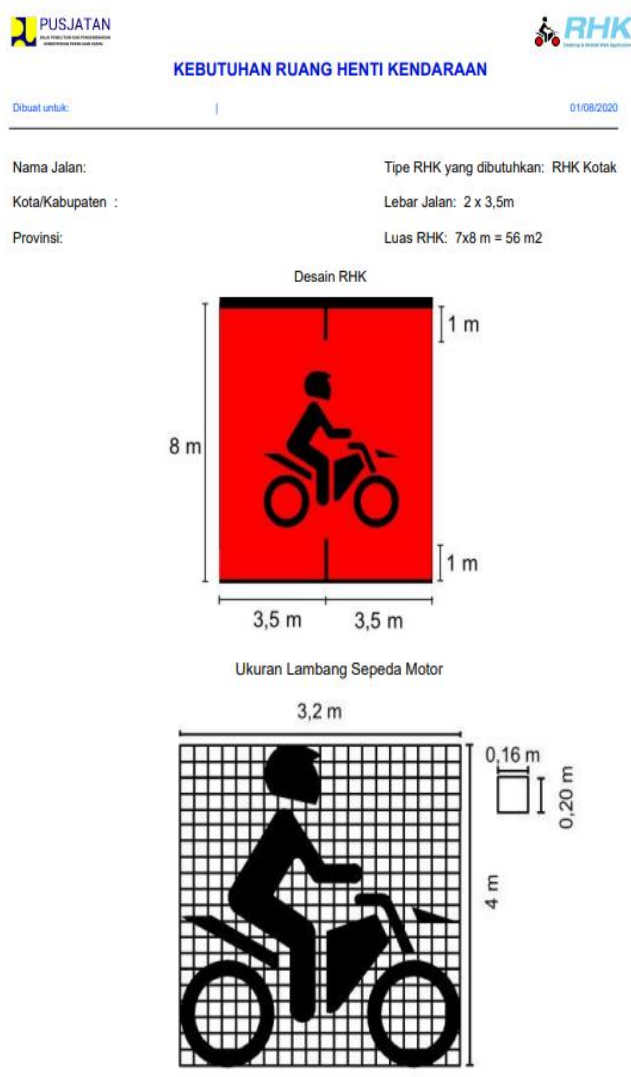

Gambar 8.

Kebutuhan Ruang Henti Kendaraan Pendekat Barat

(Sumber: Kementerian Pekerjaan Umum, 2013) 


\section{KESIMPULAN}

Berdasarkan hasil analisis kinerja simpang bersinyal dengan menggunakan metode Manual Kapasitas Jalan Indonesia (MKJI) 1997 saat terjadinya pandemi Covid-19 pada Simpang Noja - Saraswati dan perencanaan ruang henti khusus menggunakan RHK Dekstop \& Mobile Web Application, maka dapat ditarik kesimpulan bahwa :

1. Analisis kinerja simpang Noja Saraswati saat terjadi pandemi Covid-19 mempunyai nilai derajat kejenuhan (DS) yang sama pada pendekat Utara, Timur, Selatan dan Barat yaitu 0.740 . Sedangkan untuk nilai panjang antrian masing - masing pendekat yaitu pendekat Utara $60 \mathrm{~m}$, pendekat Timur 89 $\mathrm{m}$, pendekat Selatan 50, dan pendekat Barat $55 \mathrm{~m}$. Untuk nilai tundaan pada pendekat Utara $20.8 \mathrm{det} / \mathrm{smp}$, pendekat Timur $5.3 \mathrm{det} / \mathrm{smp}$, pendekat Selatan $34.5 \mathrm{det} / \mathrm{smp}$, dan pendekat Barat 13.5 $\mathrm{det} / \mathrm{smp}$.

2. Desain RHK tipe $P$ untuk pendekat Timur dan tipe Kotak untuk pendekat Barat dengan lebar $2 \times 3.5 \mathrm{~m}$ dan panjang utama $8 \mathrm{~m}$, serta untuk pendekat tipe $\mathrm{P}$ memiliki dimensi lajur pendekat $3.5 \mathrm{~m}$. Untuk pendekat Utara dan Selatan tidak dapat didesain RHK karena lebar pendekat tidak memenuhi syarat minimal $3.5 \mathrm{~m}$.

Saran yang dapat disampaikan dari hasil analisis ini yaitu:

1. Melakukan sosialisasi guna memberikan pemahaman tentang fungsi dari Ruang Henti Khusus, sehingga dapat menciptakan lingkungan jalan yang tertib dan lancar.

2. Merancang Ruang Henti Khusus masih memerlukan studi lanjutan agar dapat meningkatkan kinerja simpang, karena dalam hal ini tidak terlepas dari volume lalu lintas akibat terus adanya peningkatan pertumbuhan kendaraan bermotor roda dua.
3. Penelitian ini dapat dikembangkan terkait penyediaan Ruang Henti Khusus untuk perencanaan dimasa akan datang atau dikembangkan dengan memperhatikan aspek daya guna Ruang Henti Khusus terkait dengan kenyamanan serta kemudahan pengendara sepeda motor dalam bermanuver.

\section{DAFTAR PUSTAKA}

Departemen Pekerjaan Umum., (1997), Manual Kapasitas Jalan Indonesia (MKJI) Dirjen Bina Marga. Jakarta.

Kariyana I M, et al., (2019), Analisis Arus Jenuh Di Simpang Dengan Metode Time Slice dan MKJI 1997 (Studi Kasus Simpang Sudirman - Yos Sudarso). Bali.

Kementrian Pekerjaan Umum dan Perumahan Rakyat., (2015), Pedoman Perancangan Ruang Henti Khusus (RHK) Sepeda Motor pada Simpang Bersinyal di Kawasan Perkotaan. Jakarta.

Prasetyanto. D. et al., (2015), Perkiraan Zona Dilema Mobil Penumpang Pada Persimpangan Berlampu Lalulintas Dengan Fasilitas Ruang Henti Khusus Sepeda Motor. Bandar Lampung. The 18th FSTPT International Symposium, Unila, Bandar Lampung. Purba, Naomi A dan Daud, J., (2013), Perencanaan Ruang Henti Khusus (RHK) Sepeda Motor Pada Persimpangan Bersinyal di Medan (Studi Kasus: Persimpangan Jl. Ir. H. Juanda - Jl. Brigjend Katamso). Medan. Vol. 3, No. 1.

Pusat Penelitian Jalan dan Jembatan, Balitbang PU-Kementerian Pekerjaan Umum., (2013), http://rhk.pusjatan.pu.go.id/rhk/rhkap p.php

Ramadhani, F. et al., (2017), Analisa Kinerja Simpang Bersinyal Pingit Yogyakarta. Yogyakarta. Volume 2, No. 2. Hlm. 1-8 
Rangkuti, Nuril M., (2017), Analisa Pengaruh Ruang Henti Khusus KendaraanSepeda Motor Terhadap Kenyamanan di Persimpangan. Medan. Hlm. 73-86.

Roesdyningtyas D. A. A, et al., (2016), Kajian Rencana Penerapan Ruang Henti Khusus Sepeda Motor di Persimpangan Bersinyal (Studi Kasus Kota Malang). Malang. Jawa Timur. Volume 14, Nomor 2. Hlm. 123-129.

Sitanggang. L. H. S. et al., (2014), Analisis Kinerja Simpang Bersinyal (Studi Kasus: Jalan K.H Wahid Hasyim Jalan Gajah Mada). Sumatera Utara. Volume 3, No. 2

Tamam, M. F. et al., (2016), Analisis Kinerja Simpang Bersinyal (Studi Kasus: Jalan Tegar Beriman - Jalan Raya Bogor). Bogor. Hlm. 1-10

Tulus, M I., (2018), Analisis Kinerja Simpang Bersinyal di Kota Makasar Menggunakan Quantum GIS. Makasar. Hlm. 1-6.

Wikrama, Jaya, A.A.N.A., (2011), Analisis Kinerja Simpang Bersinyal (Studi Kasus: Jalan Teuku Umar Barat Jalan Gunung Salak). Bali. Jurnal Ilmiah Teknik Sipil Vol. 15, No. 1. Hlm . 58-71, Januari 2011.

Yulianto, A. A. et al., (2016), Model Ruang Henti Khusus (RHK) di Perempatan Lampu Merah Bogor Baru Dalam Meningkatkan Keselamatan dan Efisiensi Lalu Lintas. Bogor. Jurnal Hukum DE'RECHTSSTAAT ISSN 2442-5303 Volume 1, Nomor 2, Hlm. 181-191. Okt 2016.

Ardan Agus Yulianto, Ujang Bahar, dan Inayatullah Abdul Hasyim., (2016), Model Ruang Henti Khusus (RHK) di Perempatan Lampu Merah Bogor Baru Dalam Meningkatkan Keselamatan dan Efisiensi Lalu Lintas. Bogor.

Ayu Roesdyningtyas D. A., Achmad Wicaksono, dan Ruslin Anwar., (2016), Kajian Rencana Penerapan
Ruang Henti Khusus Sepeda Motor di Persimpangan Bersinyal (Studi Kasus Kota Malang). Malang. Jawa Timur.

Nuril Mahda Rangkuti., (2017), Analisa Pengaruh Ruang Henti Khusus Kendaraan Sepeda Motor Terhadap Kenyamanan di Persimpangan. Medan.

Sumin, L., Youguang, M.A., Chunying, Z., Shuhua, S., and Qing, H.E., (2009), The Effect of Hydrophobic Modification of Zeolites on $\mathrm{CO} 2$ Absorption Enhancement, Chinese Journal of Chemical Engineering, 17(1), pp. 36-41. 